\title{
Scrotal thermography to assess the seminal quality in Nelore and Girolando bulls
}

\section{Termografia escrotal e a relação com a qualidade seminal em touros Nelore e Girolando}

\author{
Nildo Redivo Júnior ${ }^{1}$; Camila Dutra de Souza ${ }^{1}$; Ellyn Amanda Fonseca Martins ${ }^{1}$; \\ Tatiana Issa Uherara ${ }^{2}$; Milton Mendes Cattini ${ }^{1}$; Daniel Oliveira Creste ${ }^{1}$; Felipe \\ Rydygier de Ruediger ${ }^{3 *}$; Marcelo George Mungai Chacur ${ }^{4}$
}

\section{Highlights:}

Nelore bulls sowed lower ocular globe and scrotum surface temperatures than Girolando bulls.

Nellore bulls had greater spermatic motility, vigor and fewer spermatic defects that Girolando bulls.

Nelore bulls showed greater adaptability to tropical climate than Girolando bulls.

\begin{abstract}
Bull selection by andrological examination aims to estimate the reproductive capacity of the male. Bulls of zebu origin adapt better to high temperatures than bulls of taurine origin, which may influence scrotum temperature and seminal quality due to the imbalance of testicular thermoregulation. The objective of this study was to investigate the relationship between bioclimatic variables, the temperature of body and scrotal areas, assessed with infrared thermography, and the quality of fresh and post-thawed semen in zebu Nelore bulls (Bos taurus indicus) and Girolando bulls (Bos taurus taurus x Bos taurus indicus). Bulls were kept in pickets with access to water, mineral mix and a diet supplemented with concentrate. Infrared thermographs of the scrotum, orbital globe and muzzle were performed twice a week with a Flir E40 thermal imager. For scrotal thermograms, we analyzed the temperatures of the spermatic cord, proximal and distal portion of the testes and tail of the epididymis using the Flir Tools software. Samples were collected using an artificial vagina and the ejaculates were processed and frozen in liquid nitrogen until further analyses. Data were analyzed with the Tukey test or the Kruskall-Wallis test, depending on their normal distribution. Our results showed differences $(p<0.05)$ between the two breeds regarding the temperature in the ocular globe, spermatic cord and proximal portion of the scrotum. Nelore bulls presented lower temperature in the body and in certain regions of the scrotum compared to Girolando bulls. Seminal characteristics varied between breeds, with the Nelore breed presenting better semen. Positive correlations were observed between minor sperm defects and ventral regions of the testes and tails of the epididymis in Girolando bulls. Nelore bulls were less influenced by climatic variables and presented lower temperature in skin surface areas in the infrared thermography examination compared to Girolando bulls. Nelore bulls presented superior semen quality in both fresh and thawed samples than Girolando bulls.
\end{abstract}

Key words: Infrared thermography. Testicular thermoregulation. Semen freezing. Bovine bulls.

Discentes, Programa de Pós-Graduação em Ciência Animal, Universidade do Oeste Paulista, UNOESTE, Presidente Prudente, SP, Brasil. E-mail: nildodr@hotmail.com; camiladutrasouza@hotmail.com; ellyn@unoeste.br; miltoncattini@hotmail.com; danielcreste@hotmail.com

2 Médica Veterinária, Central de Inseminação Artificial TAIRANA,Presidente Prudente, SP, Brasil. E-mail: tatiana@tairana.com

3 Pesquisador, Programa de Pós-Graduação em Ciência Animal, UNOESTE, Presidente Prudente, SP, Brasil. E-mail: f_rydygier@ hotmail.com

4 Prof., Programa de Pós-Graduação em Ciência Animal, UNOESTE, Presidente Prudente, SP, Brasil. E-mail: marcelo.chacur@, uol.com.br

* Author for correspondence 


\section{Resumo}

A seleção de touros pelo exame andrológico visa estimar a capacidade reprodutiva do macho. Touros de origem zebuína apresentam melhor adaptabilidade às altas temperaturas, em relação aos touros de origem taurina, podendo influenciar na temperatura do escroto e na qualidade seminal pelo desequilíbrio da termorregulação testicular. Objetivou-se avaliar a influência das variáveis bioclimáticas e a relação de perfis de termogramas por infravermelho de áreas do corpo e escroto com a qualidade do sêmen fresco e descongelado em touros das raças Nelore e Girolando, mantidos em Central de Inseminação Artificial. Foram utilizados quatro touros Nelore e quatro Girolando, mantidos em piquetes com acesso a água e mistura mineral; e suplementação com concentrado. Termografias infravermelhas do escroto, globo ocular e mufla foram realizadas duas vezes por semana com termovisor Flir E40. Para os termogramas escrotais, as temperaturas do cordão espermático, porção proximal e distal dos testículos e cauda do epidídimo foram analisadas utilizando o software Flir Tools. Foram realizadas colheitas de sêmen com vagina artificial e os ejaculados processados e congelados em nitrogênio líquido e analisados na pós-descongelação. Os dados passaram pelo teste de normalidade e teste Tukey; e na ausência de normalidade pelo teste KruskallWallis. Entre raças, foram observadas diferenças $(\mathrm{P}<0,05)$ nas temperaturas do globo ocular, cordão espermático e porção proximal do escroto. Os touros Nelore apresentaram menor temperatura corpórea e de regiões do escroto, em relação aos touros Girolando. As características seminais variaram entre raças $(\mathrm{P}<0,05)$, a raça Nelore apresentou sêmen de melhor qualidade. Correlações positivas $(\mathrm{P}<0,05)$ foram observadas entre defeitos espermáticos menores e temperaturas da região ventral dos testículos e das caudas dos epidídimos. em touros Girolando. Os touros da raça Nelore sofreram menor influência das variáveis climáticas com menores temperaturas de áreas da superfície da pele examinada por termografia infravermelha, em relação aos touros da raça Girolando. Os touros da raça Nelore apresentaram qualidade do sêmen fresco e descongelado superiores, em relação aos touros da raça Girolando.

Palavras-chave: Termografia infravermelha. Termorregulação testicular. Congelação de sêmen. Touros bovinos.

\section{Introduction}

The Brazilian bovine herd is mainly composed of Indian races (Bos taurus indicus) and their mixed breeds, with the predominance of the Nelore genetic group. However, the herd shows low reproductivity and the birth rate is close to $50 \%$ (Instituto Brasileiro de Geografia e Estatística [IBGE], 2015). In extensive production systems in Brazil, natural mating occurs during the hottest months of the year, when bulls are subjected to bioclimatic and environmental variations that negatively interfere with the fertility of the herd (Menegassi, Barcellos, Lampert, Borges, \& Peripolli, 2011).

The selection of bulls by the andrological exam is important to improve the herd, and the influence of the genetic composition is one of the requirements used by Artificial Insemination Centers to industrialize the semen of bulls for use in breeding programs (Chacur, Machado \& Cristancho, 2006, Sirchia, 2008, Carvalhal \& Costa, 2018).
Environments with high temperatures may compromise thermoregulation and heat dissipation mechanisms of the body, leading to thermal stress (Marai, El-Darawany, Fadiel, \& Abdel-Hafez, 2008). Infrared thermography is used to evaluate scrotal thermoregulation and physiological responses of animals raised in regions of high temperatures (Knizkova, Kunc, Gurdil, Pinar, \& Selvi, 2007) and since the 1980s, it is used as a noninvasive method to accurately measure the temperature of the surface skin of the scrotum (Coulter, Serenger, \& Bailey, 1988). Nelore bulls have been shown to adapt to thermal stress, in particular due to the anatomical characteristics typical of Bos indicus, in which the pampiniform plexus and the heat exchange mechanism played an important role in the physiological requirements for their normal reproductive performance (Brito, Silva, Barbosa, \& Kastelic, 2004). 
One way of improving the productive performance in low latitudes regions is through genetic improvement, which is done by crossing zebu and taurine breeds. The resulting offspring will exhibit greater adaptation to the tropical climate and higher potential for production (Perotto, Kroetz, \& Rocha, 2010).

The objective of this study was to investigate the relationship between bioclimatic variables, the temperature of body and scrotal areas, assessed with infrared thermography, and the quality of fresh and post-thawed semen in zebu Nelore bulls (Bos taurus indicus) and Girolando bulls (Bos taurus taurus $\mathrm{x}$ Bos taurus indicus).

\section{Material and Methods}

The project was approved by the Ethics and Animal Use Committee of the University of Oeste Paulista, under protocol 3336.

\section{Animals and study site}

During the month of May, semen samples from eight bulls were collected and frozen in liquid nitrogen: four Girolando bulls with ages ranging from 36 to 84 months, $770 \pm 24 \mathrm{~kg}$ of body weight and $38 \pm 2 \mathrm{~cm}$ of scrotal circumference, and four Nelore bulls aged 36 to 48 months, $735 \pm 21 \mathrm{~kg}$ of body weight and $37 \pm 1 \mathrm{~cm}$ of scrotal circumference. All bulls had been in a semen collection regime for 5 months and were suitable for breeding according to the norms of the Brazilian College of Animal Reproduction (Colégio Brasileiro de Reprodução Animal [CBRA], 2013). These animals were housed in an Artificial Insemination Center located in the municipality of Presidente Prudente-São Paulo, latitude $22^{\circ} 07$ ' $\mathrm{S}$, longitude $51^{\circ} 23^{\prime} \mathrm{W}$, with an average altitude of 472 meters above sea level. The city has a tropical climate with a climatic transition area and is under the influence of most atmospheric systems in South America. According to Köppen and Geiger (1928), the climate in this city is classified as $\mathrm{Cfa}$, which is characterized by humid temperate with hot summer. The climate includes a hot and rainy period between October and March, and a mild and dry period between April and September. The average temperature is $21.6^{\circ} \mathrm{C}$ with an annual average rainfall of 1,207 $\mathrm{mm}$.

During the study, all bulls were kept in pickets of $15 \times 30$ meters, formed with Brachiaria decumbens with access to the covered $4 \times 4$ meters bay with water troughs and mineral mix ad libidum and supplementation of $5 \mathrm{~kg} /$ bull/day of concentrate with $14 \%$ crude protein and $10 \mathrm{~kg} /$ bull/day Tifton hay.

\section{Study design}

Six data collections were performed, all of them repeated between $7 \mathrm{am}$ and $9 \mathrm{am}$ with intervals of 72 to 96 hours. In each collection, bioclimatic factors were measured using infrared thermograms of the scrotum, ocular globe and muzzle. Semen samples were then frozen until further analyses.

\section{Bioclimatic factors}

The monitoring of room temperature (RT), wet-bulb globe temperature (WBGT, which represents the thermal sensation or total stress in the animals), relative humidity (RH) and dry black bulb temperature $\left(\mathrm{T}_{\mathrm{db}}\right)$, which represents insolation or thermal irradiation), was performed at study site at $7 \mathrm{am}$ and $9 \mathrm{am}$ with a portable digital globe thermometer (model HT-30, InstruTemp ${ }^{\circledR}$, São Paulo, Brazil).

Subsequently, the temperature and humidity index (THI) was calculated, according to Thom (1959):

$\mathrm{THI}=0,8 \times \mathrm{T}_{\mathrm{db}}+\mathrm{RH}\left(\mathrm{T}_{\mathrm{db}}-14,4\right)+46,4$

where:

$\mathrm{T}_{\mathrm{db}}=$ dry black bulb temperature $\left({ }^{\circ} \mathrm{C}\right)$

$\mathrm{RH}=$ relative humidity (in decimals). 


\section{Infrared digital thermography}

Infrared digital thermography (Thermovisor model E40 ${ }^{\circledR}$, FLIR Stockholm, Sweden) was performed on the surface skin of the scrotum, ocular globe and muzzle, with the emitter focus of the device aligned in the caudal portion and head of each bull and perpendicularly oriented, at approximately 1.5 meters away from the bull. Using the FLIR Tools software (version 2.0.11333.1001), each thermogram was analyzed from the captured

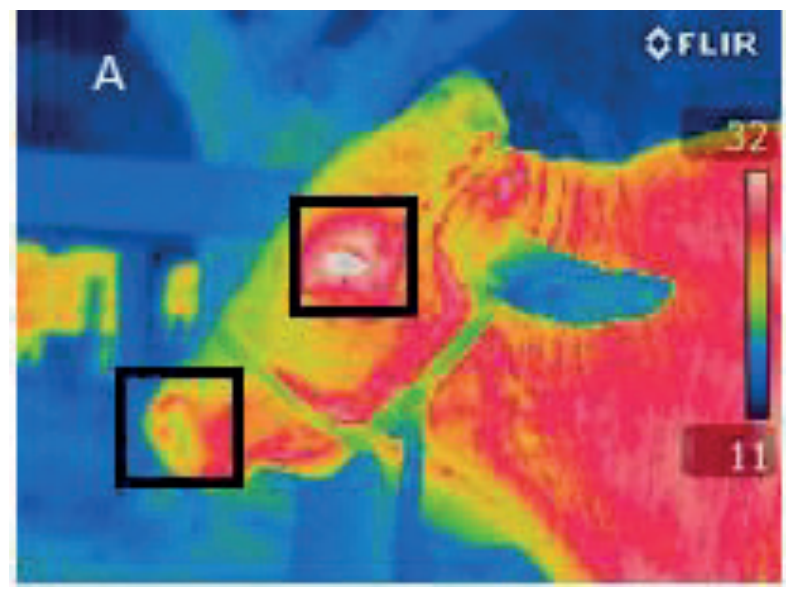

Figure 1. Infrared thermography of the orbital area, muzzle (A) and scrotum (B) of bulls.

\section{Collection and analysis of fresh semen}

Semen collection was obtained from bulls using the artificial vagina method, which causes less stress to the animal (Carvalhal \& Costa, 2018). Each bull was put together with a cow for a few minutes to induce excitation. When the bull jumped on the cow, its penis was diverted and introduced into the artificial vagina, where ejaculation occurred. The internal mucosal temperature of the artificial vagina, after being filled with water, was standardized at 42$45^{\circ} \mathrm{C}$.

The procedures for semen collection using an artificial vagina and the analyses of the quantitative and qualitative characteristics of the semen were performed according to the norms of the Brazilian image to determine the average temperature of the spermatic cord regions, proximal and distal regions of the scrotum and tail of the epididymis, on both the sides (Figure 1).

Thermography was chosen for this study because it provides a non-invasive examination without causing containment stress in bulls and because, according to Weschenfelder et al. (2013), the temperature of the ocular globe has a high correlation with body temperature.

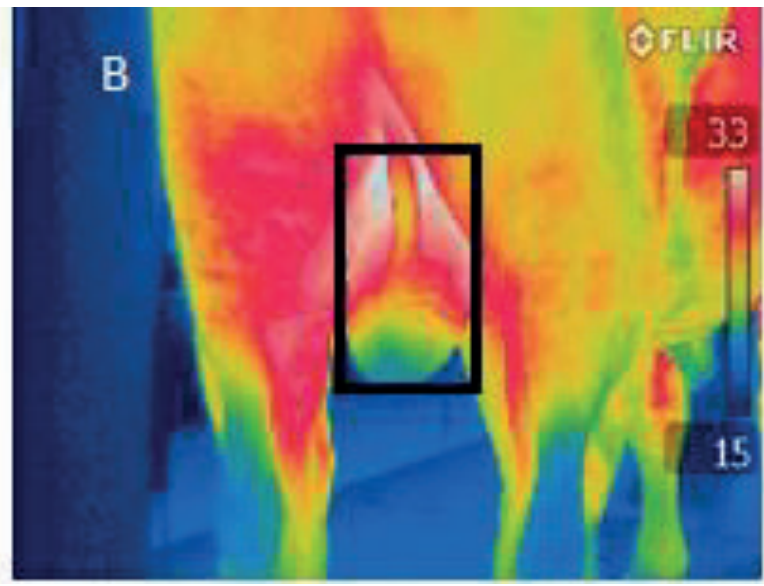


Semen freezing and post-thawing analysis

Semen freezing was performed using TRIS, egg yolk and citric acid medium, according to the rules of the Brazilian College of Animal Reproduction (CBRA, 2013). Samples were frozen in $0.5 \mathrm{~mL}$ French straws at a concentration of $30 \times 106$ spermatozoa per standardized straw. Sperm motility $(\%)$, sperm vigor (0 to 5 ) and sperm defects (\%) were analyzed after semen thawing in a water bath ( $37^{\circ} \mathrm{C} / 30$ seconds).

\section{Statistical analysis}

Infrared temperatures, seminal parameters and bioclimatic variables were analyzed using the $\mathrm{SAS} \AA$ statistical software, version 9.3 (Statistical Analysis Software, Cary, NC). Variables were analyzed by the mixed model (MIXED procedure), considering the effects of the animals as random effects, and the means of variation factors were compared using the Tukey test or the Kruskall-Wallis test, depending on their normal distribution. The relationships between infrared temperatures, seminal parameters and bioclimatic variables were analyzed using the CORRELATION procedure, and Spearman's linear correlation coefficients were calculated. Differences were considered statistically significant when $\mathrm{p} \leq 0.05$. Correlations were determined and classified according to Levine, Berenson, \& Stephan 2012.

\section{Results and Discussion}

In the present study, infrared thermographies were performed between 15 and 20 days. Examples of the areas examined are presented in Figure 1. As this period is shorter than the spermatogenesis period (57 days on average), thermography was used to accurately measure the temperature of the surface skin of the scrotum just prior to semen collection. According to Brito et al. (2004) if the temperature of the scrotum skin remains high and outside a range of 3 to $6^{\circ} \mathrm{C}$ below body temperature, spermatogenesis and androgenesis are affected. Another study reported that infrared scrotal thermography can also be used as a complementary screening test for andrological examination in field bulls, which reliably reflects the scrotal thermoregulation capacity of animals (Chacur et al., 2016).

A single thermographic image of the scrotum of each bull was obtained at each data collection, shortly after semen collection. The analysis of temperature at the six sample collections performed in Girolando and Nelore bulls showed variations in the temperatures of the body and scrotum areas. In both breeds, seminal characteristics were maintained during the samplings (Tables 1 and 2). According to Moreira (2016), environmental factors, especially temperature, may interfere with the spermatogenic cycle and semen quality. Thus, the ideal temperature of the testicles should be 3 to $6^{\circ} \mathrm{C}$ below that of the body, which occurs through thermoregulation provided by numerous physiological mechanisms, and temperatures above thermoregulation limits could compromise fertility. 


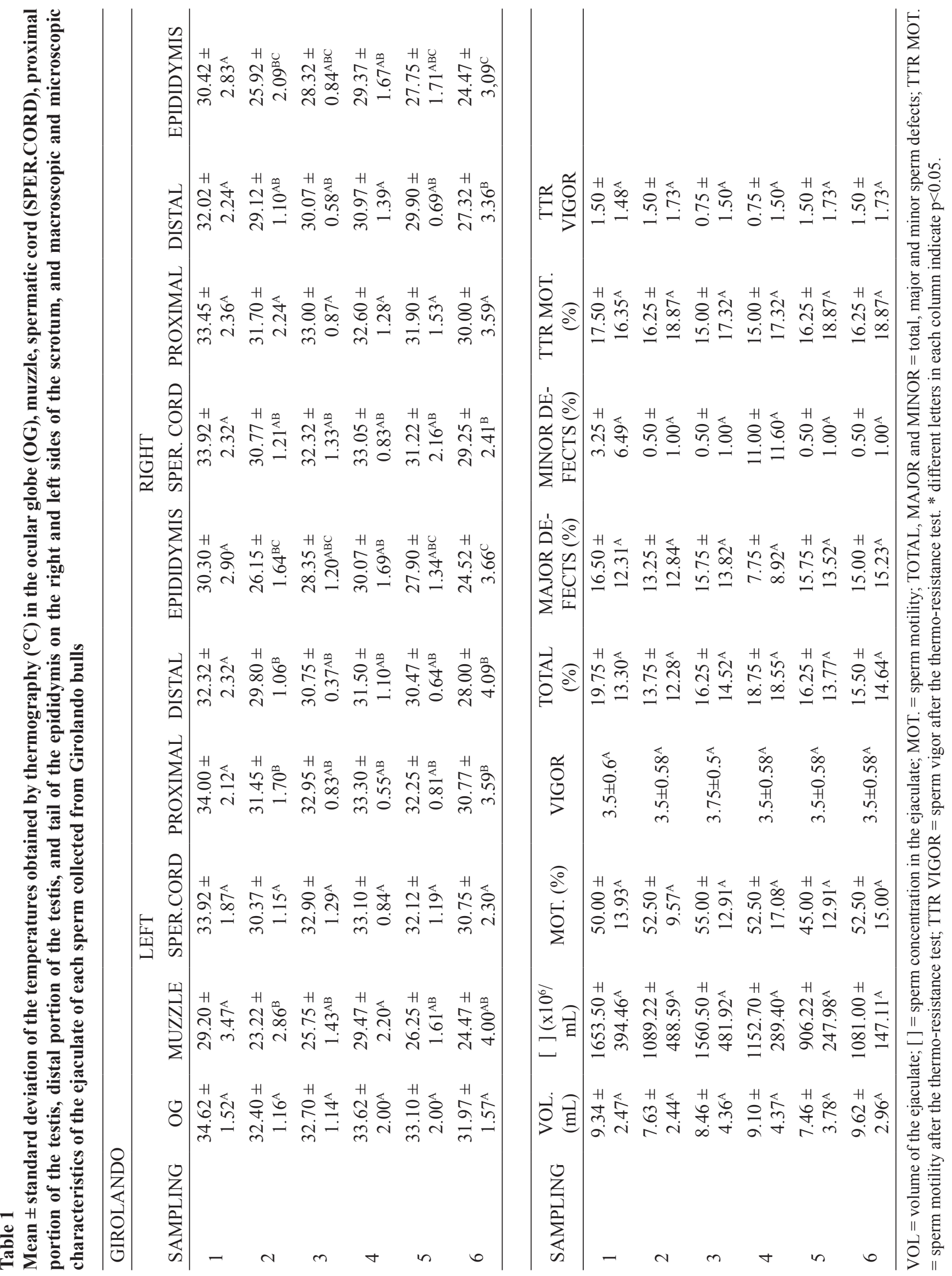




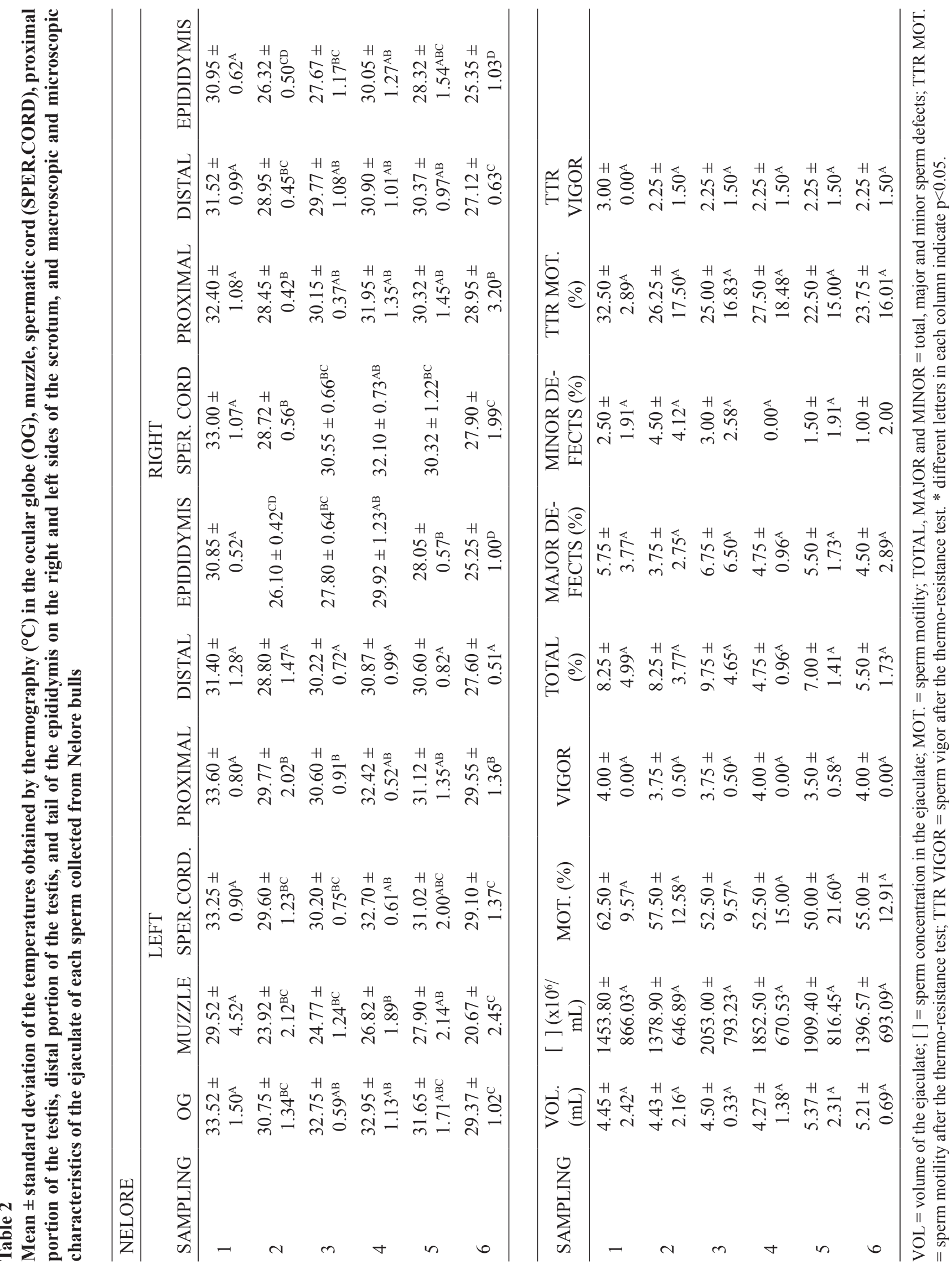


In addition to the differences observed in body and scrotal temperatures between samplings, we also observed numerical climatic variations, altering room temperature, wet-bulb globe temperature, dry black bulb temperature and relative humidity (Table 3). We observed a positive medium-to-strong correlation between THI and body temperature measured by thermography (ocular globe and muzzle) and temperatures of the scrotum (spermatic cord, proximal and distal region of the testis and tail of the epididymis) on the right and left sides (Table $4, \mathrm{P}<0.05$ ). Nogueira et al. (2013) emphasized that room temperature and thermal comfort provided to the animals during the use of the equipment directly influence the thermogram results. In the present work, the absence of variations in seminal characteristics between collections indicate that oscillations in the temperature of scrotum surface in the two breeds were controlled, without affecting the seminal profile of the animals (Ruediger, Chacur, Alves, Oba, \& Ramos, 2016). Kastelic (2014) reported that a moderate increase in testicular temperature in bulls drastically reduces sperm production, progressive sperm motility and live sperm count per ejaculate, and increases the percentage of morphologically abnormal spermatozoa.

All thermograms of the scrotum and ocular globe were obtained when their surfaces were dry. The skin of the scrotum on rainy days (wet with water) can influence the temperature of the surface of the scrotum and cause its considerable decrease, and 30 minutes are required for the temperature to stabilize after the skin is dry (Chacur et al., 2016).
Comparing both breeds, differences in the temperature of the eyeball, spermatic cord and proximal portion of the scrotum were observed on both the right and left sides, with Nelore bulls presenting lower temperature in the scrotum and ocular globe than Girolando bulls. Seminal characteristics also varied among these breeds. Although Nelore bulls presented lower volume of ejaculate, it had higher sperm concentration, sperm motility and sperm vigor, lower incidence of sperm defects and greater TTR resistance than Girolando bulls (Table 5). Ruediger et al. (2018) observed that body surface temperatures measured with the thermograph can be used to identify heat stress due to the positive correlation of these points with rectal temperature and plasma cortisol levels. Weschenfelder et al. (2013) found that imaging the eye surface allows the detection of temperature changes associated with physiological conditions. Stewart (2008) correlated the increase in ocular temperature with the elevation of thermal stress. Therefore, it has been demonstrated that Girolando bulls are more susceptible to high temperatures than Nelore bulls, and that the latter presents greater adaptability to tropical climate.

Although the Girolando and Nelore breeds have a distinct adaptation to climate factors, these factors influence spermatogenesis. However, this influence can be minimized by using strategies to improve thermal comfort, such as natural or artificial shading of the pastures (Renaudeau et al., 2012). 


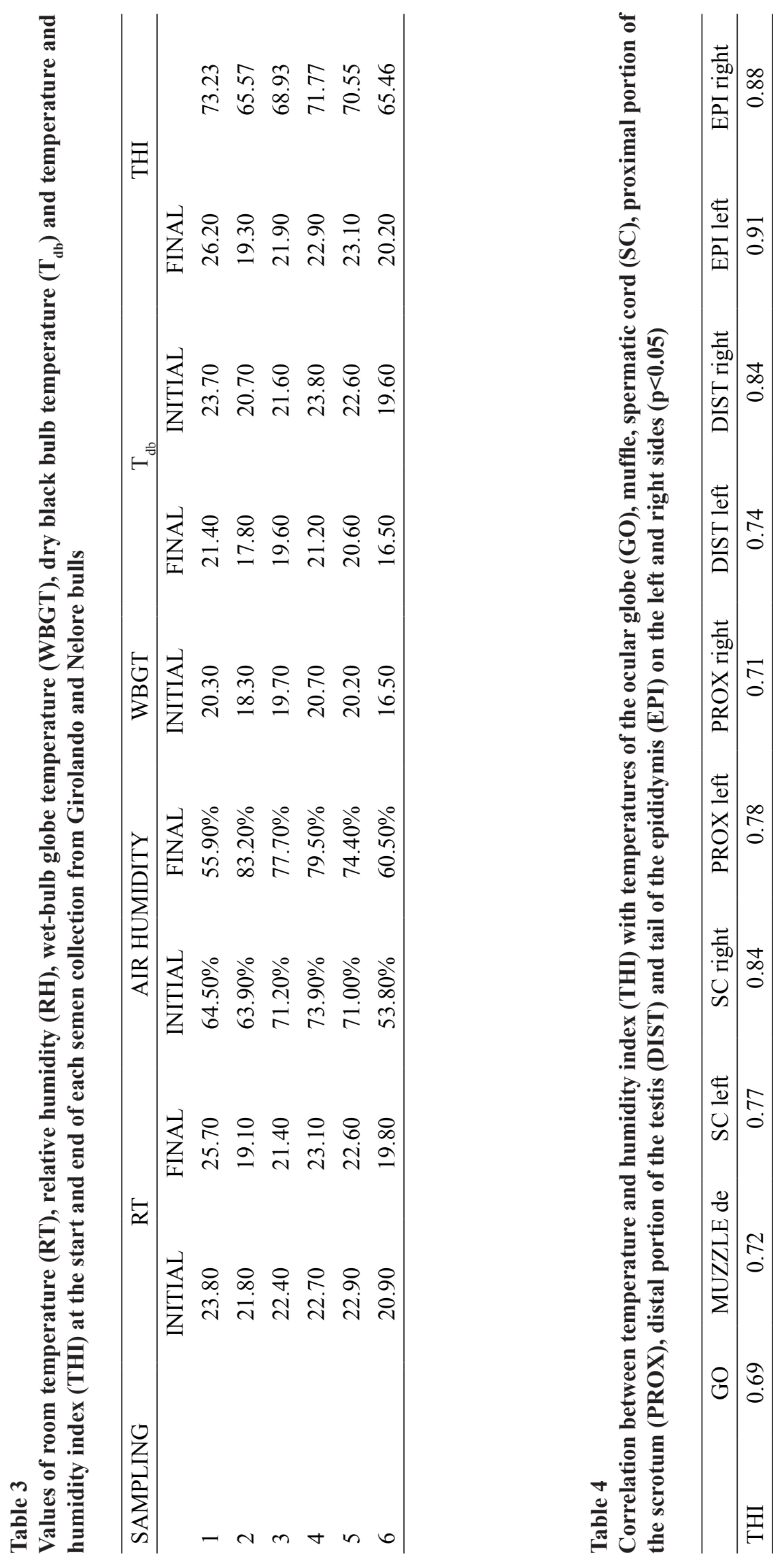




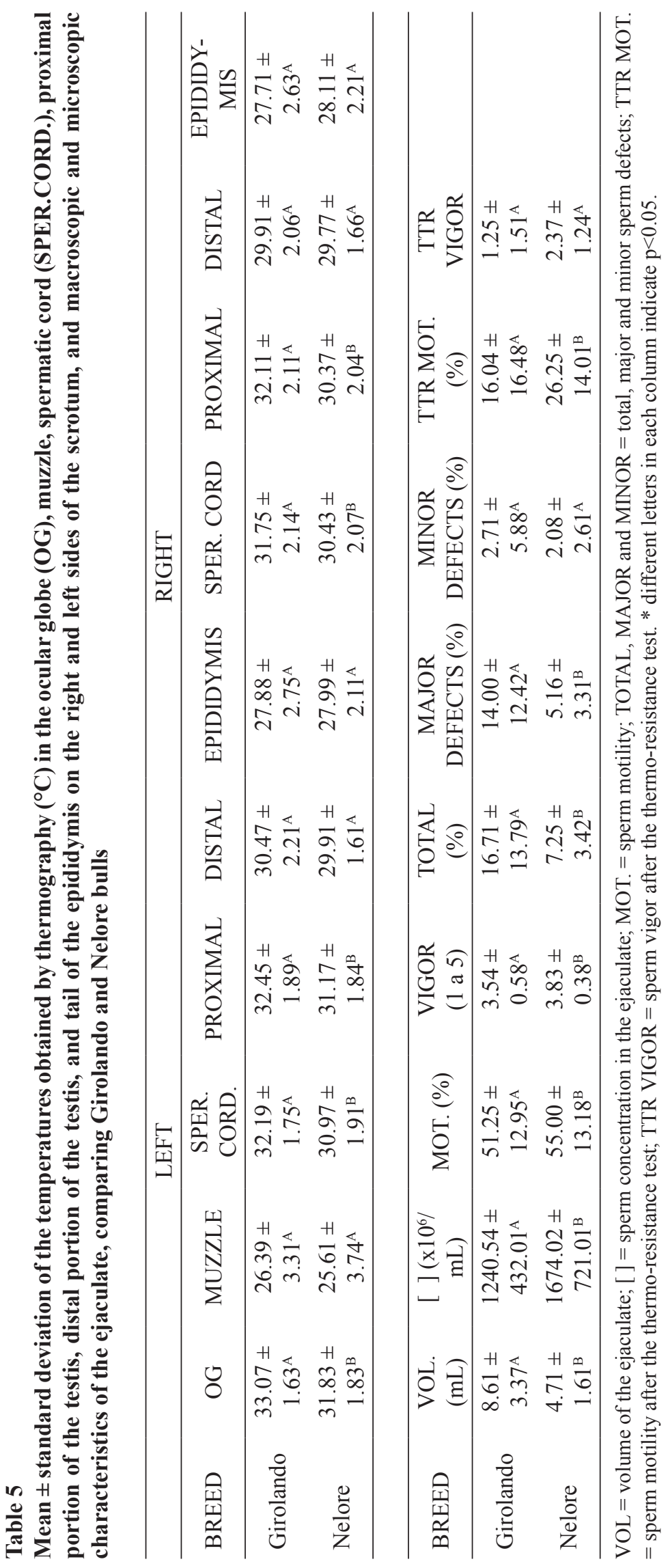


If the environment is inadequate and does not favor physical processes (radiation, conduction, convention) (Despopoulos, 2003), the physiological mechanisms need to adjust according to the climate, thereby increasing the sweating, respiratory rate and peripheral vasodilatation (Swenson, Reece \& Dukes, 1996). However, when these mechanisms become inefficient due to the environment, the animal undergoes thermal stress, which reduces fertility. In addition, thermal stress decreases food intake by the animal, which leads to a reduction in heat dissipation and metabolism (Bernabucci et al., 2010), reduced somatotropin production (Rhoads et al., 2009), and increased insulin (Wheelock, Rhoads, Van Baale, Sanders, \& Baumgard, 2010) and serum cortisol levels (Chacur et al., 2010), affecting growth and reproductive efficiency.

Another important aspect is the adaptation of zebu breeds to tropical climate (i.e. temperature, frequent solar irradiation and high relative humidity of the air). This was demonstrated in Brahman and Nelore bulls (Chacur, Miyasaki, Oba, Souza, \& Gabriel, 2017; Ruediger, Chacur, Alves, Oba, \& Ramos, 2016), which present as main adaptive characteristics skin thickness, dark coloration, white pelt, higher concentration of sweat glands and greater skin irrigation than mixed or taurine animals (Silva \& Pocay, 2001). It is known that the thermoregulation mechanisms of the male reproductive organ are not totally efficient (Losano et al., 2018). In the case of thermal stress, the increase in scrotal/testicular temperature occurs, thereby increasing cellular metabolism in the testicles, which leads to a higher $\mathrm{O}_{2}$ need (Kastelic, Wilde, Rizzoto, \& Thundathil, 2017). Testicular blood supply is limited and will not be enough to supply the increase in $\mathrm{O}_{2}$ demand in testicular cells, which leads to cell death and testicular degeneration, affecting both spermatogenesis and androgenesis (Paul, Teng, \& Saunders, 2009). Due to a lower adaptability to tropical climate, Girolando bulls may suffer from chronic thermal stress, which may result in subfertility or infertility.

A medium positive correlation between the ventral portion of the left testicle and sperm vigor after the thermoresistence test $(\mathrm{r}=0.44, \mathrm{p}<0.05)$ was observed in the Nelore breed when correlating thermography temperatures with sperm quality. In the Girolando breed, a medium positive correlation was found between the temperature of the ventral portion of the left testicle and sperm concentration, as well as with smaller spermatic defects. Similar results were observed between the ventral portion of the right testicle and the right and left side of the epididymis with smaller spermatic defects (Table 6). Similarly, Souza et al. (2014)' extensively observed correlations of the different regions of the scrotum of Nelore bulls with seminal quality, reinforcing the importance of testicular thermoregulation in spermatogenesis and androgenesis.

Table 6

Correlations between the temperatures measured by infrared thermography and seminal characteristics of Girolando bulls. Only significant correlations are shown $(\mathbf{p}<0.05)$

\begin{tabular}{lll}
\hline & Minor defects & Sperm concentration \\
\hline Ventral portion of the testicle & 0.49 & 0.42 \\
Ventral portion of the testicle & 0.45 & \\
Tail of the epididymis & 0.53 & \\
Tail of the epididymis & 0.52 & \\
\hline
\end{tabular}




\section{Conclusions}

Lower temperatures were measured in certain areas of the surface skin of the scrotum examined by infrared thermography in Nelore and Girolando bulls. The quality of fresh and post-thawed semen was higher in the Nelore breed. Bioclimatic parameters influenced more broadly the temperature at the surface skin of the scrotum and the quality of fresh semen and post-thawing in the Girolando breed.

\section{Referências}

Bernabucci, U., Lacetera, N., Baumgard, L. H., Rhoads, R. P., Ronchi, B., \& Nardone, A. (2010). Metabolic and hormonal acclimation to heat stress in domesticated ruminants. Animal, 4(7), 1167-1183. doi: $10.1017 / \mathrm{S} 175173111000090 \mathrm{X}$.

Brito, L. F. C., Silva, A. E. D., Barbosa, R. T. \& Kastelic, J. P. (2004). Testicular thermoregulation in Bos indicus, crossbred and Bos taurus bulls: relationship with scrotal, testicular vascular cone and testicular morphology, and effects on semen quality and sperm production. Theriogenology, 61(2-3), 511-528. doi: 10.1016/S0093-691X(03)00231-0

Carvalhal, M. V. L., \& Costa, F. O. (2018). Principais aspectos sobre bem-estar de touros mantidos em centrais de coleta de sêmen. Revista Brasileira de Zoociências, 19(2), 249-264.

Chacur, M. G. M., Miyasaki, A. A., Oba, E., Souza, C. D., \& Gabriel, L. R. A., F ${ }^{\circ}$ (2017). Body and testicular development and serum testosterone concentrations in Brahman males. Semina: Ciências Agrárias, 38(4), 2561-2579. doi: 10.5433/1679-0359.2017v38n4Supl1p2561

Chacur, M. G. M., Souza, C. D., Andrade, I. B., Pepino, G., Bastos, F. L. G. D., Souza, M. G. R., \& Marques, A. D. P., Jr. (2016). Aplicações da termografia por infravermelho na reprodução animal e bem-estar em animais domésticos e silvestres. Revista Brasileira de Reprodução Animal, 40(3), 88-94.

Chacur, M. G. M., Aurélio, P. T. F., Oba, E., Laposy, C. B., Scalon, O., Jr., Inague, L., \& Kronka, S. N. (2010). Influency of one nutraceutic on semen, testosterone, cortisol, eritrogram and body weight in young bulls Bos taurus indicus. Semina: Ciências Agrárias, 31(2), 439-450. doi: 10.5433/1679-0359.2010v31n2p439
Chacur, M. G. M., Machado, N. B., Neto, \& Cristancho, D. R. (2006). Winter-springer and Summer influence upon seminal plasma proteins in bulls. Animal Reproduction, 3(2), 251-260.

Colégio Brasileiro de Reprodução Animal [CBRA]. (2013). Procedimentos para exame andrológico $e$ avaliação de sêmen animal. Belo Horizonte: CBRA.

Coulter, G. H., Serenger, P. L., \& Bailey, D. R. C. (1988). Relationship of scrotal surface temperature measured by infrared thermography to subcutaneous and deep testicular temperature in the ram. Journal of Reproduction and Fertility, 84(2), 417-423.

Despopoulos, A. (2003). Completely revised and expanded. Color Atlas of Physiology ( $5^{\text {th }}$ ed.). Stuttgart: Thieme.

Instituto Brasileiro de Geografia e Estatística [IBGE]. (2015). PPM 2014: rebanho bovino alcança 212,3 milhões de cabeças. Recuperado de http://saladeimprensa.ibge. gov.br/noticias.html? view=noticia\&id $=1 \&$ idnoticia $=3006 \&$ busca $=1 \& \mathrm{t}=$ ppm-2014rebanho-bovino-alcanca-212-3-milhoes-cabecas

Kastelic, J. P. (2014). Understanding and evaluating bovine testes. Theriogenology, 81(1), 18-23. doi: 10.1016/j.theriogenology.2013.09.001

Kastelic, J. P., Wilde, R. E., Rizzoto, G., \& Thundathil, J. C. (2017). Hyperthermia and not hypoxia may reduce sperm motility and morphology following testicular hyperthermia. Veterinarni Medicina, 62, 437-442. doi: 10.17221/124/2016-VETMED

Knizkova, I., Kunc, P., Gurdil, G. A. K., Pinar, Y., \& Selvi, K. C. (2007). Applications of infrared thermography in animal production. Journal of Faculty of Agriculture, 22(3), 329-336.

Köppen, W., \& Geiger, R. (1928). Klimate der Erde. Gotha: Verlag Justus Perthes. [Wall-map $150 \mathrm{~cm} \times 200 \mathrm{~cm}]$.

Levine, D. M., Berenson, M. L., \& Stephan, D. (2012). Estatística: teoria e aplicações (6 ${ }^{\text {th }}$ ed.). Rio de Janeiro: LTC.

Losano, J. D. A, Angrinami, D. S. R., Dalmazzo, A., Rocha, C. C., Brito, M. M., Perez, E. G. A.,... Nichi, M. (2018). Efect of Vitamin E and polyunsaturated fatty acids on cryopreserved sperm quality in Bos taurus bulls under testicular heat stress. Animal biotechnology, 39(2), 100-109. doi: 10.1080/10495398.2017.1322973 
Marai, I. F. M., El-Darawany, A. A., Fadiel, A., \& AbdelHafez, M. A. M. (2008) Reproductive performance traits as affected by heat stress and its alleviation in sheep. Tropical and Subtropical Agroecosystems, 8, 209-234.

Menegassi, S. R. O., Barcellos, J. O. J., Lampert, V. N., Borges, J. B. S., \& Peripolli, V. (2011). Bioeconomic impact of bull breeding soundness examination in cow-calf systems. Revista Brasileira de Zootecnia, 40(2), 441-447. doi: 10.1590/S151635982011000200028

Moreira, G. M. (2016). Primeiro estudo do uso de termografia escrotal em touros Girolando e sua relação com a classificação andrológica por pontos. Dissertação de Mestrado, Universidade Federal de Lavras, Lavras, Brasil.

Nogueira, F. R. B., Souza, B. B., Carvalho, M. G. X., Garino, F. Jr., Marques A. V. M. S., \& Leite, R. F. (2013). Termografia infravermelha: uma ferramenta para auxiliar no diagnóstico e prognóstico de mastite em ovelha. Revista Brasileira de Medicina Veterinária, 35(3), 289-297.

Paul, C., Teng, S., \& Saunders, P. T. K. (2009). A single, mild, transient scrotal heat stress causes hypoxia and oxidative stress in mouse testes, which induces germ cell death. Biology of Reproduction, 80(5), 913-919. doi: 10.1095/biolreprod.108.071779

Perotto, D., Kroetz, I. A., \& Rocha, J. L. (2010). Milk production of crossbred Holstein $\times$ Zebu cows in the northeastern of Paraná State. Revista Brasileira de Zootecnia, 39(4), 758-764. doi: 10.1590/S151635982010000400009

Renaudeau, D., Collin, A., Yahav, S., Basilio, V., Gourdine, J. L., \& Collier, R. J. (2012). Adaptation to hot climate and strategies to alleviate heat stress. Livestock Production Animal, 6(5), 707-728. doi: 10.1017/S1751731111002448

Rhoads, M. L., Rhoads, R. P., Baale, M. J., Collier, R. J., Sanders, S. R., Weber, W. J.,... Baumgard, L. H. (2009). Effects of heat stress and plane of nutrition on lactating Holstein cows: I. Production, metabolism, and aspects of circulating somatotropin. Journal of Dairy Science, 92(5), 1986-1997. doi: 10.3168/ jds.2008-1641

Ruediger, F. R., Chacur, M. G. M., Alves, F. C. P. E., Oba, E., \& Ramos, A. A. (2016). Digital infrared thermography of the scrotum, semen quality, serum testosterone levels in Nellore bulls (Bos taurus indicus) and their correlation with climatic factors. Semina: Ciências Agrárias, 37(1), 221-232. doi: 10.5433/1679-0359.2016v37n1p221

Ruediger, F. R., Yamada, P. H., Barbosa, L. G. B., Chacur, M. G. M., Ferreira, J. C. P., Carvalho, N. A. T., \& Oba, E. (2018). Effect of estrous cycle phase on vulvar, orbital area and muzzle surface temperatures as determined using digital infrared thermography in Murrah buffalo. Animal Reproduction Science, 197, 154-161. doi: 10.1016/j.anireprosci.2018.08.023

Statistical Analysis System (SAS). (2011). SAS/STAT user's guide: statistics. v.9.3. Cary, NC: Statistical Analysis System.

Stewart, M. (2008). Non-invasive measurement of stress and pain in cattle using infrared thermography. Tesis, Animal Science, Massey University, Palmerston North, New Zealand.

Silva, R. G. D., \& Pocay, P. L. B. (2001). Transmissão de radiação ultravioleta através do pelame e da epiderme de bovinos. Revista Brasileira de Zootecnia, 30(6), 1939-1947.

Sirchia, F. P. (2008). Relação entre circunferência escrotal, libido, hormônios e características do sêmen em touros Brangus e Pardo suiço. Dissertação de Mestrado, Universidade do Oeste Paulista, Presidente Prudente, SP, Brasil.

Souza, C. D., Chacur, M. G. M., Ruediger, F. R., Cartocci, J. S., Andrade, I. B., Bastos, G. P.,... Ramos, A. A. (2014). Termorregulação escrotal em touros Nelore (Bos taurus indicus). Colloquium Agrariae, 10, 101106. doi: 10.5747/ca.2014.v10.nesp.000143

Swenson, M. J., Reece, W. O., \& Dukes. (1996) Fisiologia dos animais domésticos. São Paulo: Guanabara Koogan.

Thom, E. C. (1959). The discomfort index. Weatherwise, 12(1), 57-60.

Weschenfelder, A. V., Saucier, L., Maldague, X., Rocha, L. M., Schaefer, A. L., \& Faucitano, L. (2013). Use of infrared ocular thermography to assess physiological conditions of pigs prior to slaughter and predict pork quality variation. Meat Science, 95(3), 616-620. doi: 10.1016/j.meatsci.2013.06.003

Wheelock, J. B., Rhoads, R. P., Baale, M. J., Sanders, S. R., \& Baumgard, L. H. (2010). Effects of heat stress on energetic metabolism in lactating Holstein cows. Journal of Dairy Science, 93(2), 644-655. doi: $10.3168 /$ jds.2009-2295 
